\title{
8. Collective organization in platform companies in Argentina: between trade union traditions and adaptive strategies
}

\author{
Cora Arias, Nicolás Diana Menéndez and \\ Julieta Haidar
}

\section{INTRODUCTION}

This study is a contribution to the debate around the possibilities of workers' collective action and union organization in platform capitalism (Vandaele 2018; Collier et al. 2017; Tassinari and Maccarrone 2019). In brief, this debate engages with the organizational difficulties facing workers who find themselves in a paradigm of work in which companies promote the figure of the entrepreneur and self-employment, refusing to recognize the existence of an employment relationship, in practice as well as before the law.

Various studies (Jolly 2016; Rosenblat 2016; Vandaele 2018) assert that there is greater potential for workers' organization on the platforms known as on demand, through apps; meaning those for which work is done offline, taking a physical form, in a specific circumscribed territory (De Stefano 2016). In this perspective, these characteristics create better conditions for workers to form alliances, a situation which is rather more difficult on crowdwork platforms, which have hundreds of workers spread across the internet.

In this vein, the study produced by Collier et al. (2017) emphasizes that Uber workers find themselves in more advantageous conditions for coordinated action, due to four characteristics: a high level of control over working conditions, Uber itself being the single target of complaints shared by drivers, the existence of physical spaces where drivers can meet up during their working hours (such as airports), and the emergence of blogs and forums on which information circulates. However, these authors maintain that it has not been transport unions but rather 'substitute' actors (other unions, alternative labour 
organizations, lawyers) who have more often taken the lead in defending the drivers' interests and demands, generally in courts and legislatures.

In summary, the characteristics of labour organizations on the platforms pose serious challenges for workers' coordination and collective action, and even in more advantageous situations (on offline platforms), it is not clear that the unions can take on the task. Thus, the question of the effectiveness of the unions as the main organizational form for workers is a particularly pertinent one in the light of the new challenges engendered by platform capitalism. The question is whether an institution born more than a century ago to confront the exploitation of factory labour, after almost five decades of an offensive on the part of capital and the worsening of working conditions and rights, has the capacity to restore a relative balance between labour and capital in the face of algorithmic exploitation.

In our consideration this is a complex question, and in order to attempt to respond it is necessary to move beyond a decontextualized standpoint. We understand unions to be a socio-historical category which has gone through transformations along with changes to the society of which it is a partial expression. As Hyman points out, treating unions as though they were formal organizations plucked out of their social context is to disregard the impact of the institutional framework of power which the unions continuously interact with (Hyman 1975). In this regard, analysing union responses to platform capitalism requires that we consider a group of aspects with the aim of outlining the complexity of the phenomenon; among other aspects: global tendencies and pressures, business strategies, the characteristics of labour relations models, and types of unions.

In a prior study (Haidar et al. 2020), we analysed how the characteristics of algorithmic management, i.e. the supervisory practices, governance and control of the workers carried out by algorithms (Möhlmann and Zalmanson 2017), create conditions that obstruct or facilitate workers' organization, and how those organizations harness those resources of power in order to resist the platform capitalists' offensive and advance their demands. To put it another way, in that study we showed that in order to understand the characteristics of workers' organizational processes, it is necessary to take a view which transcends the organization itself and analyse how the platform companies organize the labour process.

On the basis of the progress made in our research, we understand that algorithmic management stakes out possibilities and limitations for the construction and use of resources of union power. In this chapter we aim to incorporate another dimension into our analysis which engages with the ways in which the unions respond to the challenges of platform work: the trade union traditions.

For the purposes of this study, we define trade union traditions as the ensemble of discursive and extra-discursive practices that influence the modalities of 
intervention, the styles of political-union construction, and the levels of institutional plasticity of a union organization. Modalities of intervention refers to the repertoires of collective action, the styles of political-union construction relate to types of leadership and the modes of decision-making, and institutional plasticity refers to the capacity to interpret and process the changes occurring in the composition of the workforce and the activities it engages in. Traditions are social constructions, and are therefore dynamic, and the object of transformations and disputes.

In this chapter we analyse the responses of two unions organizing platform delivery workers in Argentina: the Association of Platform Workers (APP), and the Association of Motorcyclists, Messengers and Services (ASIMM) that possess characteristics associated with two different union traditions. Expressed schematically: the first union is more associated with a rank and file type of organization, with horizontal and combative features, while the latter is closer to a hierarchical, vertical, bargaining-oriented organization.

This case is relevant because in Argentina the unions hold significant social and political power and continue to constitute the main form of workers' organization in spite of the processes which have weakened the workers' movement, from successive military coups throughout the 20th century to the neoliberal offensive which was initiated in the mid-1970s and intensified in the 1990s. The processes of organization and struggle undertaken by delivery workers are an expression of this strength. On the one hand, APP was founded in 2018 as the first platform workers' union in Latin America, when the structural conditions and the profile of the workers seemed to deter organization. On the other hand, ASIMM is an occupation-based union (couriers) that pre-existed the phenomenon of platforms and which faces a challenge from these new companies, as well as the new group of workers with different profiles and dynamics.

On the basis of qualitative research conducted in the city of Buenos Aires, ${ }^{1}$ we analyse the positions and actions taken by each organization in the light of the algorithmic management of delivery platforms, according to the characteristics of traditional unions they adopt, not in terms of stereotypes or fixed models, but as extracted types which were constructed in the analysis (McKinney 1966). The practices of APP and ASIMM are not immutable, but rather undergo transformations in the process of interaction between both organizations, the workers, the companies and governments.

The Argentinian experience is of interest insofar as it highlights the fact that although the platform companies are indeed powerful, and organize the labour process in such a way that the existence of employment relations is obscured, which creates huge obstacles for workers' organization and struggle, there are several dimensions that can contribute to combating these difficulties: the degree of power held by unions in society, the characteristics of traditional 
unions, the levels of institutional plasticity of the unions, the winning of partial victories in a longer term struggle, and the political-ideological orientations of governments.

This chapter is arranged into four sections: first, we outline a brief characterization of the main union traditions in Argentina; second, we describe the development of delivery platforms in Argentina; and in the third and fourth sections we analyse the two organizational experiences of delivery workers, taking into consideration the dimensions of analysis of union traditions: styles of construction, modalities of political-union intervention, and institutional plasticity. Lastly, in the final conclusions we analyse the two experiences of organizing and highlight what the main contributions of this study are to the research field of unions and platform work.

\section{THE UNION MODEL IN ARGENTINA}

From their birth at the end of the 19th century, workers' organizations have been a key political actor in Argentina. Anarchist and communist ideas transmitted by immigrants arriving mainly from Italy and Spain over that period exerted a strong gravitational influence during the emergence of local labour unionism (Suriano 2001): they formed cooperatives, unions and associations that delivered social services to the workers and also organized protest action and struggles such as strikes and boycotts. With the assumption of Juan Perón's government (1943-1955), workers acquired new rights and unions multiplied in number while increasing their power, coming to constitute the 'backbone' of Peronism.

The vagaries of Argentinian political and economic history affected the unions, which enjoyed two periods in which they held greater power and others in which they were displaced from power. However, even in the most adverse conditions for workers, the unions continued to wield authority and their participation in the political arena was indisputable.

Union life in Argentina is governed by the Trade Union Law which establishes that workers have the right to freely form union organizations to defend their economic interests (according to official data from 2016, there are currently 3,376 unions). The law requires that organizations submit an application to the Ministry of Labour in order to obtain state recognition, requesting registration in a special union register. Once that application has been completed, unions acquire 'union registration' and along with it a series of rights. However, the Ministry only grants 'union recognition' to the most representative union in the sector (that with the greatest number of dues-paying members), which confers exclusivity or priority in relation to certain rights, fundamentally collective bargaining rights (according to the official data of the 3,376 registered unions only 1,667 have state recognition). 
Despite state incentives for workers' organizational unity, in contemporary Argentina there are various cases of union diversity and coexistence in the same economic sector (Arias 2010). Furthermore, various rulings from the Supreme Court of Justice have ushered in the possibility of constructing rank and file organizations with the same rights as the unions granted state recognition.

Over the period of their existence, we can identify two major union traditions in Argentina which here we reconstruct and characterize with the aim of being able to interpret the experiences of ASIMM and APP more clearly. In a schematic way, we define the first tendency as being bargaining oriented, and the other as more confrontational.

The bargaining tradition in Argentina is characterized by a vertical style of political-union construction, featuring limited plurality, and decision-making capacity concentrated in the hands of the leadership. With regards to the modalities of intervention, political-institutional bargaining with governments and companies takes precedence, and the resource of collective action is scarcely utilized. Similarly, in terms of institutional plasticity, we can observe a high degree of permeability with regards to the context, and a tendency towards frequent appeals to the administrative authorities.

The confrontational tradition features a style of political-union construction that incorporates a larger degree of plurality and prioritizes rank and file decision-making in assemblies, with less static leaderships. Collective action plays a prominent role in its modalities of intervention, with political-institutional bargaining as a complementary resource. With regards to its institutional plasticity, this tradition is characterized by greater permeability when processing new identities and demands.

In the 1990 s these traditions found expression in two main union confederations: the General Confederation of Labour (CGT), founded in 1930, represents the bargaining tradition, ${ }^{2}$ and the Argentinian Workers' Confederation (CTA), established in 1992 as an opposition to market reforms, represents the confrontational tradition. The crystallization of both of these traditions into two separate confederations should not obscure the historical lineage of workers' organizations in Argentina, which Gilly (1986) described as the 'Argentinian anomaly'. This anomaly lies in the high levels of activism and politicization of the rank and file in the workplaces, which historically has put pressure on unions to make more substantial demands beyond the political-institutional alliances made by the union leadership.

The other aspect of this anomaly is institutional power. Indeed, a noteworthy feature of the Argentinian union traditions is the greater orientation of demands to the government rather than to capital, which Bunel (1992) points out as a fundamentally political hallmark of action, above all the level of the union leaderships (Diana Menéndez 2017). 
In between these poles of bargaining and confrontation, attempts to reach agreements with governments and rank and file movements, the dynamic of organizing the delivery workers' struggle in Buenos Aires developed. The two experiences which we analyse in this chapter, APP and ASIMM, enable us to explore the diverse modes of confronting the challenges represented by the new modalities of management and exploitation. To further that aim, some of the questions which orient our research into the positions and actions taken by the unions are: How to organize a new group of workers who often do not recognize themselves as such? How are demands presented to companies that refuse to recognize the employment relationship? What are the regulatory proposals that could guarantee rights without relinquishing the benefits of autonomy?

\section{DELIVERY PLATFORMS IN ARGENTINA}

The delivery platforms operating in Argentina are Rappi, Glovo and PedidosYa. ${ }^{3}$ These were established in almost ideal conditions: (1) a neoliberal government (under the presidency of Mauricio Macri from 2015-2019) which promoted entrepreneurship and the dismantling of institutions which protected labour rights; (2) a labour market characterized by rising unemployment (7.2 per cent in the fourth quarter of 2017, 9.1 per cent in the same period in 2018 according to official data), and the precarization of working conditions; (3) the arrival of various groups of immigrants, mostly Venezuelans, needing to quickly find work; and (4) the pre-existence of food delivery as a pattern of consumption.

Indeed, the appearance of these companies was facilitated by the government by a law passed in 2017 ('Support for Entrepreneurial Capital'), which expedited the creation of businesses with negligible capital, in only 24 hours. Likewise, the government promoted a labour reform which included a new legal figure in Argentinian legislation: the autonomous employee. According to the government, this figure would enable a new regulatory framework for new types of workers, such as riders, but the unions and labour lawyers opposed the initiative warning that the project would flexibilize and increase the precarization of employment, starting with riders but later extending to all workers.

Although the government promoted the operation of these new companies, the delivery service model is not a new one in Argentina; the difference being that while previously businesses employed their own delivery workers or subcontracted other companies to provide them with delivery workers, the new platforms use technology based on algorithmic management to connect supposedly independent workers with customers and providers. Therefore, riders are considered to be self-employed workers who can work when and how they 
wish, without there being any employment relationship from the perspective of the companies themselves, which is concealed by the discourse of entrepreneurship and algorithmic management. In fact, while the companies promise that riders can connect how and when they wish, in the concrete practices we can observe that the algorithms organize and control the labour process and the workers: they constantly monitor and assess the riders' behaviour, implement decisions automatically, and modify their working and payment practices and the rules of the game unilaterally and without prior warning (Haidar et al. 2020).

Currently the different delivery companies operating in Argentina conform to these characteristics. While PedidosYa had started to operate in Argentina in 2010 as a go-between for providers and customers, and later began to hire workers under a contractual arrangement, after the arrival of Rappi and Glovo onto the scene, it adapted to the new management model and started to use independent riders without any type of employment relationship. The fact that PedidosYa was the first platform company to use contracted employees meant that ASIMM, the pre-existing union, became the main organizer and representative of its workers. APP, in contrast, was founded by activists working for Glovo and Rappi, with the latter being the strictest in terms of controls, and with the worst track record of mistreatment and lack of protection for workers (Haidar et al. 2020). Over the following paragraphs we will analyse in detail the positions and actions taken by both unions in relation to the workers, the companies and the government.

\section{3 \\ APP: FROM RANK AND FILE ORGANIZATION TO POLITICAL OUTLET}

Simón Rodriguez, the famous Venezuelan educator, coined a phrase that two centuries later would be put into practice by some of his compatriots: 'Either we invent or we fail'. In October 2018 a group of riders applied to the Secretary of Labour for the Nation for union registration for the Association of Platform Workers (APP), the first platform workers' union in Latin America. The union's constitution - still not recognized by the Ministry for Labour - was the expression of a preceding organizational process carried out by platform delivery workers in the city of Buenos Aires.

\subsection{Styles of Political-Union Construction}

The organization of work on delivery platforms opened the possibility for workers to meet in a new workplace: the streets. Delivery workers are highly visible (they ride bicycles or motorbikes with large eye-catching red, yellow or orange boxes) and they are a ubiquitous presence on bicycle lanes and the 
pavements outside restaurants while they wait for food packages to deliver. Rappi riders have the most free time for meetings as the company does not organize delivery shifts, while on Glovo and PedidosYa the distribution of shifts and the permanent assigning of deliveries means that spare time allowing communication between workers is reduced.

The possibility of face-to-face meetings and the discontent generated by the maltreatment workers experience from the companies (sudden unilateral changes to working conditions, lack of response to queries and proposals posed by the delivery workers, delays in payments, etc.) created the conditions in which Rappi riders have become the architects of collective organization. The delivery workers, predominantly Venezuelans and Colombians, began to share - first on a face-to-face basis, and then through WhatsApp groups - their concerns and complaints about abuses on the app, which was crucial to constructing a commonly held interest and an identity as workers. After virtual meetings they developed the process of organization and started to hold face-to-face meetings, taking the form of a kind of informal assembly which was held in the main neighbourhoods of Buenos Aires.

Gradually, without any external guidance to signpost the way, problems which a priori seemed of a personal nature began to be constructed as collective demands: working hours, rest periods, health insurance and health and safety, wages, and transparency of information. Driven by a sensation of injustice, the workers' organization began to grow from below. WhatsApp groups were set up, along with meeting points for each of the main neighbourhoods in the city, and in each one a representative or leader emerged who collected complaints and offered advice. The traditional Argentinian figure of the rank and file workplace delegate returned through this new experience. Workers we interviewed perceived this phenomenon as follows: 'She (an activist) is a lion ... she is the struggle, a fighter. You (Argentinians) are world famous for your unions and mobilizations: that's her' (personal interview with Rappi worker).

'If he (an activist) said today we won't work, in Belgrano (a neighbourhood in Buenos Aires) nothing would move and that's a third of the platform' (personal interview with a lawyer for APP).

As mobilization theory (Tilly 1978; Kelly 1998; Darlington 2002) and historical experience suggests, the leaders constituted the main organizers of discontent; it was they who provoked the transition from complaints to direct action which we will analyse below: strikes, boycotts and mobilizations. It was of crucial importance to the process that a group of labour lawyers with strong links to the Confederation of Argentinian Workers (CTA) approached the assemblies and their leaders. The CTA, as mentioned above, is a confederation rooted in the rank and file union tradition and open to the organization of new groups of workers. These lawyers helped the riders, who were mostly 
migrants with no prior union experience, to develop an awareness of the need to organize their union, APP.

The formal constitution of the union, with members and delegates, represented more of a means than an end, in other words it was a path to obtaining recognition of the employment relationship (Haidar et al. 2020). The argument was as follows: there is an economic, organizational and legal relationship, there is also a union, therefore there is a relationship of employment.

As occurred in Argentina at other historical moments in which a new occupation with new workers and modes of working appeared (such as call centres in the first few years of the 21 st century), the emergence of a new union was not the first option chosen by the workers. On the contrary, the riders initially contacted the pre-existing union ASIMM, but the relationship proved to be highly conflictive; the riders' leaders successfully organized struggles with a collective character, they wanted to make progress with their demands, and they found themselves in conflict with a union that wanted to control them. A worker explained it in this way:

When we left (a meeting with company representatives after a strike) ... as if by magic representatives from the motorbike couriers' union (ASIMM) appeared to tell us that they were going to help us, that they were going to negotiate with the company because this couldn't be allowed to happen, that they were going to join us, blah blah blah; they invited us to go to the union building the next day (...) What ASIMM did was they told us to calm down, not to talk to the media, that they had resolved everything, that they were going to hire employees. It turns out that the agreement was only to hire 22 workers per month, when there were 6,000 of us registered. (Personal interview with Rappi worker)

ASIMM's efforts to contain the activists included threats and physical attacks on APP representatives, practices which are well-established in a tradition for which the struggle for union control between different factions had long been expressed through violence, and practices which persist till today in a minority of male-dominated unions. After these experiences, the links between the riders' leaders and ASIMM were severed completely, and their paths bifurcated as the former set up their own union.

\subsection{Modalities of Intervention}

The dynamic guiding APP was marked by direct action as the main protest mechanism: boycotts, mobilization and strikes. On the one hand, the workers took advantage of their high degree of visibility in the city of Buenos Aires and the discussion of the phenomenon of platforms in the media to make their demands public. In a kind of cultural boycott, they used social networks and invitations to participate in television programmes in order to denounce their 
exploitative working conditions and in that way tarnish the reputation of the platform companies.

A boycott is a tactic used by old trade unions and is fundamental to the service sector. In this case the measure was successful, taking into consideration that the issue became widely discussed (in public opinion) and that the companies' spokespeople had to make public statements defending themselves.

On the other hand, the riders also organized mobilizations, a tool generally used by Argentinian unions, above all when the possibilities of calling a strike are limited (due to the union's uncertain capacity to win its members to the action, or the limited impact that the strike would make), or when the aim is to have a political influence on the government rather than the company. The mobilizations organized by the delivery workers corresponded with a combination of these factors. First, the riders demonstrated outside the companies' offices with the goal of being acknowledged and gaining admittance. Once the organizational process was well under way, the delivery workers also mobilized outside the Secretariat for Labour in order to demand employment regulations. On certain occasions they attracted the support of social organizations who joined the mobilizations, realizing the possibility of articulating the struggle with other precarious sectors.

In this case the action was unsuccessful, the national government and the local government of the city of Buenos Aires did not acquiesce to the workers' demands; on the contrary, they ideologically and practically supported the companies. However, thinking beyond the immediate outcome, the action taken shows that the delivery workers rapidly absorbed lessons from the traditional Argentinian unions and availed themselves of a traditional recourse in union history in Argentina: seeking protection and negotiation with the government, an aspect which we will explore in more detail below.

The third and most resonant tactic was the strike, a worker's right which is deeply enshrined in Argentinian law. The labour process was simultaneously a learning process for the workers, who with time learnt that if they refused to carry out deliveries, the business would grind to a complete halt and the platforms would be adversely affected.

With this idea at the forefront, Rappi riders took strike action using an original technique: one Sunday in July 2018 at a peak business hour they met in the commercially busiest neighbourhood squares, remained connected to the app, but made no deliveries for over an hour. In order to carry out this protest action they needed the participation of a large number of workers, coordinated geographically with the assistance of the WhatsApp groups.

The strike was effective, since as could be predicted the orders accumulated in local businesses, causing huge losses for the platforms. Multiple phenomena were expressed in this protest action: the worker's capacity for organization and leadership, but also the limits of rank and file action in platform capital- 
ism. After the strike, the company invited the activists to participate in talks and responded positively to the demand for an increase in delivery rates. However, sometime later the activists were blocked from the app: effectively the company had sacked them. In this way Rappi was able to restrain the workers, generating fear and seriously weakening their collective action. This was partly a reflection of the limitations of the rank and file action taken by workers confronting companies which hold tremendous power at a global scale, with the backing of governments which allow them to operate without regulations, and the characteristics of algorithmic management which impose order, which control and which punish surreptitiously.

\subsection{Institutional Plasticity}

In spite of the lack of clarity or agreement about the possible modalities of employment (indefinite employment contracts, day labour or some form of self-employment), the demands of the workers organized through APP were focused on winning a raft of protection encompassing working hours, rates, health insurance, health and safety. This set of demands was mainly aimed at the state, as a union organizer explained:

... we are asking the state to stop taking an indifferent stance because this should have been controlled from the outset. Who is it that regulates? The state (...) If the state doesn't regulate this then who will? (...) The law covers these problems and has ways to deal with them, what we need is for the state to take action against these companies that are waving around the false slogan of freelance and are creating precarity at a thousand kilometres an hour. (Personal interview, APP activist)

This union sought to achieve regulation for the work and the employment relation, and did not promote or support a strategy aimed at prohibiting this type of work altogether. This became evident in their disagreement with the ruling of a judge in the city of Buenos Aires who, dealing with the case of the platforms' infringement of urban health and safety measures, ordered their suspension (which was never carried out).

The prosecution of the activity of the platform companies had been advocated by ASIMM in a strategy which, as we shall examine in the following section, was intended to pressure the companies either to conform to the typical modality of employment or to close down. This prohibitionist stance could not repress the demands of workers who above all wanted to maintain their source of work and the relative freedoms that the platform system permits.

APP, by contrast, appealed to the courts to demand the reinstatement of leaders who had been blocked (fired) for their union activity, and in this way they aimed to demonstrate the existence of an employment relationship with the company. These court cases alternated between progress and repeated set- 
backs over the course of 2019 and still have no definitive outcome. The interesting aspect of this process is that the union, after having been weakened by the effective dismissal of its organizers and suffering a depleted workers' participation, began to move away from the practice of rank and file mobilization and towards a strategy sharing more in common with the political-institutional tradition.

In interviews we conducted in 2019 with new rank and file workers (it is an occupation with high levels of turnover), we observed that very few were aware of the existence of APP and its previous struggles, that they were broadly satisfied with the platforms, and that they had no interest in union organizing. The union activists we interviewed during the same period remarked that the workers were wary of unions due to the fear of being dismissed or losing their job as a result of a court ruling that could force the companies to suspend their activities.

Along with this characterization of the relation of forces in terms of the relative weakness of the union as compared with the platforms, the activists incorporated the most traditional mode of defining strategy particular to Argentinian unions: interpreting and adapting to the political conjuncture by taking into account who is currently in governing positions of power, and how they could benefit or harm them. This reflects a high degree of institutional plasticity, meaning a capacity to interpret and process transformations in occupations and the composition of the labour force, changing union strategies as a result.

Hence, activists who a year previously had organized assemblies and protest action, now placed their hopes in the idea that a change of government in Argentina would benefit them (in October 2019 Alberto Fernández of the more worker-friendly Peronist party was elected president). Their expectations regarding the new government were: that APP would be granted legal recognition through administrative channels (union registration) which the previous government had denied them; that through legislative channels it would pass legislation to regulate the occupation and enshrine labour rights; and that through legal channels a resolution would be enacted which would compel companies to reinstate sacked union leaders. With regards to the outcomes of these expectations, it is important to point out that halfway through 2021, there has been no advance towards the legal recognition of APP, nor towards a legal resolution regarding the dismissal cases; however, the new government is drafting a project to enact a 'statute' for platform workers, ${ }^{4}$ which would be a regulatory tool that establishes rights and obligations for workers with highly flexible working hours (in Argentina there is an already existing statute for domestic, rural and construction workers among others).

The reconstruction and analysis of the development of delivery workers' organization in a new union reveals various elements that contribute to think- 
ing about different union strategies towards large platform companies. First, the importance of the historical legacy of unionism in Argentina given that the (young, migrant) workers took an early decision to form a union instead of another more original type of organization as occurred in other countries where workers faced the same phenomenon. Second, the tradition of a rank and file, participative and direct action-oriented unionism has enabled workers to achieve certain progress with their demands but has also revealed its limitations in confrontation with the power of the platforms. Among these achievements, one which stands out is the construction of an identity for the riders as workers and as part of a workers' collective in opposition to an employer-other which the platform companies represent; raising platform work as an issue on the public and governmental agenda; and winning an immediate demand, an increase in rates paid, as a result of an innovative protest action, the virtual strike. At the same time, the experience highlights the fact that when confronting powerful companies without government support, direct action without institutional union recognition has serious limitations, as exemplified by the fact that after agreeing to increase delivery rates the companies continued to operate without recognizing the employment relationship, and then turned to a classic tactic of industrial conflict: following the strike, union activists were sacked (blocked), with a subsequent disciplinary process applied to the whole group of workers. Third, the institutional plasticity of the union proved to be key to recognizing the limitations of direct action and shifting to pursuing a political-institutional strategy, a practice which is familiar to the bargaining tradition of unions in Argentina. Fourth, a government with a political-ideological orientation which is more favourable to workers can indeed contribute to resolving conflicts via political channels; conflicts that, given an unfavourable correlation of forces, would be difficult to resolve through industrial action.

\section{ASIMM: A MODEL TO DISMANTLE}

ASIMM is a union with state recognition which adheres to the most rigid union model here called bargaining, although it has a relatively recent history. It was founded in 2001 to represent couriers who were employed by small and medium-sized businesses. The sector was disrupted by the emergence of platforms, the implementation of online administrative procedures, and the expansion of e-commerce, which overall had the effect of reducing the demand for courier services. Along with the decline of the sector ASIMM lost members; only a few years previously the union had around 5,000 members, and the number fell to less than half that in 2019.

The abrupt decline of membership and the radical transformations in the sector called in to question the validity of the established union model. 
Likewise, the emergence of a new union (APP) reflects the inability of the established union to adequately deal with the working conditions, demands and expectations of a new group of workers. However, ASIMM went through a process of relative adaptation, shifting from very rigid positions towards greater flexibility.

\subsection{Styles of Political-Union Construction}

ASIMM is affiliated to the CGT, the oldest and most traditional of the Argentinian union confederations. The iconography associated with ASIMM, both on social network sites as well as at their offices and headquarters, is replete with symbols associated with Perón's leadership, with Catholicism and nationalism; all features of a conservative political-ideological orientation. Furthermore, courier services are carried out on motorbikes and its workers are strongly associated with a masculine 'biker' culture and heavy metal. In fact, there is no woman in the upper echelons of the union.

In contrast with that tradition, the appearance of platforms attracting a new group of young migrant workers on bicycles, and with many women (although still not constituting a majority), changed the characteristics of the rank and file. The new workers became objects of suspicion for the union, as an organizer expressed it:

... There is a shocking problem here that there are kids from Glovo who steal from each other, they eat the food orders ... 'I'll order some food myself, I'll eat it, and then I'll say that my customer didn't want the order but actually I ate it' ... It's all just anarchy ... There's a photo on Google of a guy that ordered a pizza and they ate half of it before he got it delivered .... (Personal interview, ASIMM leader)

Thus, ASIMM was unreceptive to the demands that the new generation of workers were raising, among them the possibility of exercising the benefit of labour rights while also conserving their autonomy in relation to working hours. In this regard, the union defended a more traditional concept of employment which implied, among other aspects, fixed working hours:

A kid from Rappi said 'I want to be registered', and we said 'but it would be good if you knew which days you are going to work ... Friday, Saturday and Sunday at least', and he answered 'no, on Fridays I play football and Tuesdays I can't work ...', so actually do you want to work at all? (Personal interview, ASIMM leader)

From the perspective of the traditional interpretive framework of the union, the new demands and interests that the workers proposed were alien to them, something which found expression in the thwarted dialogue with the workers who would eventually go on to set up APP. Over time, with the growth of 
the number of platform workers and the emergence of APP, ASIMM found itself obliged to modify its discourse and accept the existence of a new labour force: young women and men, a large section of whom rode bicycles (very little in common with biker culture), and a majority of whom were Venezuelan migrants.

\subsection{Modalities of Intervention}

ASIMM's first intervention into the conflict took place immediately following the strike organized by Rappi workers described above. One of the recommendations the union made was to not discuss the strike publicly in the media, which is an approach that stems from the union tradition prioritizing bargaining and conceives of conflict as a last resort. Thus, ASIMM approached Rappi to negotiate the hiring of a limited number of workers as contracted employees, a position that was rejected both by the company and by the rank and file leaders who saw this bargaining position as a betrayal of their collective demands. This, added to the violent intimidation of the rank and file activists, marked a parting of the ways between ASIMM and the workers who would later organize themselves through APP.

After the negotiations collapsed, ASIMM implemented new modalities of intervention and made a turn towards collective action, principally mobilizations outside public institutions and 'noise demonstrations' (a gathering of workers with implements that make noise to attract attention) outside company offices. A leader describes it:

We organized marches to the Ministry, last November we held a mobilization at the obelisk [a famous monument in central Buenos Aires] with the Argentine Federation of Transport Workers to see if we could raise public awareness a bit .... (Personal interview, ASIMM leader)

The mobilization at the obelisk, supported by other transport unions, placed the debates and demands in a context with broader social resonance: provoking a public debate about the conditions of platform workers. Similarly, the conflict which was sparked off in PedidosYa towards the end of 2018, when the company dismissed 400 registered workers in order to shift to a new model of self-employed delivery workers, motivated the union to support the sacked workers. On that occasion the workers decided to occupy an administrative office belonging to the company.

This marked a turning point for ASIMM, which from then on began to collaborate with and support the delivery workers. While the dismissals directly impacted the main rank and file base of the union, as they were contracted 
workers, the action taken by ASIMM forged links with other workers who valued the close relationship with an already established union structure:

... it was more a question of acceptance, of lowering our guard with people from ASIMM ... We started to realize that there was a lot of prejudice against ASIMM, and we got to know them, they were there and it was the only political group that stepped in and dealt with the sackings and made it a much wider issue ... they opened up a lot of spaces for us in the union and a lot of places where we could also help the rest of the workforce .... (Personal interview, PedidosYa activist)

The visibility of the conflicts and the threat of a rank and file organization in competition for the representation of platform workers encouraged ASIMM to modify their modalities of intervention and relax their resistance to incorporating new workers.

\subsection{Institutional Plasticity}

Initially, ASIMM clung firmly to the institutional logic which leaves no space for the representation of informal workers. Even the union itself had institutional barriers to incorporating new workers:

the statute says that we can register employed workers, even though affiliation is voluntary, it's just a question of joining ... We can't enrol them in the system because there has to be an employer, we can't give them a membership number to be more specific .... (Personal interview, ASIMM leader)

The union strategy seems to exclusively revolve around demanding from the administrative authorities that the platform companies formally employ their workers, recognizing the employment relationship and thus subscribing to the collective bargaining agreement. There does not seem to be a strategy of encompassing the diverse forms of work that would provide leadership to and empower the organization of rank and file workers. On the contrary, from the union's perspective, the state was the only actor that could, through political-institutional channels, resolve the problems that arose as a result of the new mode of working: 'Whenever we noticed that the company breached a regulation, we reported it, the problem is that if the state, which should be penalizing infractions, does nothing, we have our hands tied ...' (personal interview, ASIMM leader).

The demands aimed at pressuring the state and the companies included a strategy to ban the new form of work for breaching the existing regulations, but in a politically adverse context (the neoliberal government of Mauricio Macri between 2015 and 2019) that was ineffective, above all due to the unfavourable balance of forces with regards to the power of the companies. Given 
these limitations on the deployment of a traditional bargaining strategy aiming to subsume platform delivery work under existing institutional frameworks, ASIMM underwent an internal overhaul that involved a higher degree of institutional plasticity. As mentioned above, this was expressed in the willingness to support the workers' demands with protest action and attempts to devise a collective agreement that would specifically cover the new characteristics of platform work. In that regard, ASIMM, along with APP, hoped that a new government would be more receptive to the union's demands; an expectation that corresponds with the union tradition of relying on political channels to resolve industrial conflicts.

An analysis of the positions and actions taken by ASIMM at different moments enables us to account for some noteworthy features of traditional unionism facing the phenomenon of platform work. First, a distinctive feature of the Argentinian case compared with experiences in other countries is the pre-existence of a specific union for couriers and delivery workers, which is possible due to the union model of forming organizations along occupational lines, even when the particular economic sector is relatively small. In principle, the existence of a specific pre-existing union provided delivery workers with more advantageous conditions in which to organize. Second, this experience shows that the bargaining tradition has drawbacks when entering into conflict with multinational companies operating at an international level that refuse to recognize the existence of employment relations, and which evade regulations. Third, it demonstrates that the willingness of a union to adjust its original conservative positions and develop greater institutional plasticity is key to broadening its base and sphere of action, incorporating workers with new identities, demands and forms of taking action. Fourth, a union from the bargaining tradition is better placed to intervene and win demands when there is a government with a more worker-friendly political-ideological position, one that is willing to use political channels to attempt to partially balance out the power inequalities that exist in the industrial sphere. In view of the new government's project to draft a statute for platform workers, the focus of political unionism that directs its demands towards the state seems to have regained effectiveness in the context of the reality imposed by the platform companies.

\section{CONCLUSIONS}

The unprecedented speed at which these transformations to labour processes have recently taken place has had an impact on academic and political debates. The end of work, the disappearance or weakening of the unions, the crisis of the established labour relations model are now questions discussed globally. In this chapter we have been concerned with analysing the potential that the unions have to organize platform workers and to confront companies that 
appropriate the discourse of entrepreneurialism and algorithmic management in order to conceal the existence of employment relations and evade regulations.

Drawing on our analysis of the process of organization and struggle undertaken by delivery workers in two unions in Argentina, we are able to outline some conclusions that can contribute to examining union strategies facing global platform companies. An initial conclusion we can draw from this experience is that the historical legacy of unionism has an impact on the definition of the ways in which workers organize. In Argentina the unions have been and continue to be a powerful social force, and local legislation facilitates the creation of unions with relative ease; meaning that on the one hand, before the delivery platforms existed there was a pre-established union for the occupation (ASIMM), and on the other hand, when a group of riders became dissatisfied with that union, they were able to take the decision to form their own union (APP). Although most delivery workers are young migrants with no prior union experience, they set up their own union rather than alternative forms of organization.

The second conclusion is that the characteristics of the trade union traditions influenced the ways in which the unions organized the riders and acted on their demands; these traditions enabled them to win partial victories but were not sufficient in themselves to confront the power of the platform companies. In one case, APP developed strategies more akin to those of a rank and file, participatory, direct action-oriented unionism, which permitted them to accomplish some objectives, principally the construction of a workers' identity, placing the issue firmly on the public stage, and winning some immediate demands (an increase of delivery rates), but which did not manage to overturn the platforms' logic of refusing to recognize any employment relationship. ASIMM, rooted in the bargaining tradition, attempted to negotiate the hiring of workers with the companies, following established models of labour organization, with little success.

The third conclusion we can draw from this study is that the challenges posed by platform companies have compelled these traditions to adopt greater flexibility, and overhaul concepts, practices and strategies. In this regard, we can observe that what here we describe as institutional plasticity is key to the unions ability to respond to the new forms of capitalist production and new worker subjectivities.

Similarly, a fourth conclusion, related to all those above, indicates that while the unions were not immediately successful in the demands they brought before the platform companies, their partial achievements were crucial to advancing towards their goals in the longer term. In contrast with the discourse of entrepreneurialism, the self-identification of the workers as workers, and raising the precarization of platform workers as a problem in the public 
agenda, are key steps towards constructing the conditions that may enable them to gradually win their demands.

A fifth preliminary conclusion on the basis of this case, taking the political dynamics into consideration, is that the political-ideological orientation of the government is important, insofar as government support can contribute to achieving through political channels what cannot be resolved by direct action or bargaining with the companies. In this regard, while under a pro-business government (Mauricio Macri, 2015 to 2019) the companies enjoyed the opportunity to operate without regulation in Argentina, the change of government for one with a more worker-friendly orientation (Alberto Fernández from the end of 2019) seems to have presented the opportunity to establish a statute for platform work that would enshrine labour rights for delivery workers.

It is not possible to make generalizations from the Argentinian case; however, it does offer some dimensions of analysis which could have a favourable impact on workers' processes of organization and struggle, and which could fruitfully be incorporated into the field of union studies in platform capitalism, among them: the degree of power held by unions in society, the characteristics of trade union traditions, the degree of institutional plasticity demonstrated by the unions, the contributions of partial victories to the longer-term struggle, and the political-ideological orientations of governments.

\section{NOTES}

1. We have constructed our data on the basis of in-depth interviews: we conducted a first round of interviews with activists and leaders from the two unions studied between July and December 2018, when APP was at the height of its organization and struggle. Throughout 2019 we held a second round of interviews, with rank and file workers and again with union activists and leaders, in a period of retreat for APP. This diversity of experiences during the periods in which we were conducting our interviews enabled us to analyse the dynamics and complexities of the processes of union organization. Additionally, we have analysed union statutes and public discourse in the media and on social networks.

2. Neither of the two union confederations constitute a hegemonic block. The CGT in particular has been riven by internal disputes around a diversity of positions and strategies. In the 1990s a significant sector of the CGT strongly opposed market reforms but without formally abandoning their institutional affiliation.

3. Rappi was founded in Colombia in 2015 and arrived in Argentina in February 2018. Glovo was founded in Barcelona in 2005 and also arrived in Argentina at the beginning of 2018. PedidosYa was established in Uruguay in 2009, and from 2014 its main shareholder has been the German company Delivery Hero. PedidosYa has been running in Argentina since 2010 as an intermediary platform linking customers and businesses, and in 2017 incorporated its own delivery workers. In 2019 UberEats began operating, but given its short operational span so far, it is not an object of analysis in this chapter. 
4. The 'Statute for On-Demand Platform Workers' is a project from the Argentinian Ministry for Labour. According to the draft we were able to review in March 2020, it is a statute specifically for riders. It establishes, among other things, regulations for maximum weekly working hours and rest time, a minimum guaranteed wage, a sickness and health and safety regime, and a regulatory framework for disciplinary action.

\section{REFERENCES}

Arias, C. (2010), 'Existencias precarizadas', Gestión de las Personas y Tecnología, 8, $26-35$.

Bunel, J. (1992), Pactos y agresiones, Buenos Aires: FCE.

Collier, R., Dubal, V. and Carter, C. (2017), 'Labor platforms and gig work: The failure to regulate', IRLE Working Paper No. 106-17. From http://irle.berkeley.edu/files/ 2017/labor-platforms-and-gig-work.pdf

Darlington, R. (2002), 'Shop stewards leadership, left wing activism and collective workplace union organization', Capital and Class, 76, 95-126.

De Stefano, V. (2016), "The rise of the "just-in-time" workforce: On demand work, crowdwork, and labor protection in the "gig economy", Conditions of Work and Employment Series, ILO, 71. From https://wcd1.ilo.org/wcd1/groups/public/--ed_protect/---protrav/---travail/documents/publication/wcms_443267.pdf

Diana Menéndez, N. (2017), 'Representaciones inconclusas: dinámicas de constitución de identidades político sindicales en organizaciones gremiales', Enfoques, 27 (XV), 123-148.

Gilly, A. (1986), 'La anomalía argentina (Estado, corporaciones, trabajadores)', in P. González Casanova (ed.), El Estado en America Latina. Teoría y práctica, México: Siglo XXI, pp. 187-214.

Haidar, J., Diana Menéndez, N. and Arias, C. (2020), 'La organización vence al algoritmo (?) Plataformas de reparto y procesos de organización de los trabajadores de delivery en Argentina', Revista Pilquen, 23, 15-28.

Hyman, R. (1975), Industrial Relations. A Marxist Introduction, Basingstoke: Palgrave Macmillan.

Jolly, C. (2016), 'Collective action and bargaining in the digital era', in M. Neufeind, J. O'Reilly \& F. Ranft (eds), Work in the Digital Age: Challenges of the Fourth Industrial Revolution, London: Rowman and Littlefield International, pp. 209-223.

Kelly, J. (1998), Rethinking Industrial Relations. Mobilization, Collectivism and Long Waves, London: LSE/Routledge.

McKinney, J. (1966), Constructive Typology and Social Theory, New York: Appleton-Centrury-Crofts.

Möhlmann, M. and Zalmanson, L. (2017), 'Hands on the wheel: Navigating algorithmic management and Uber drivers autonomy', International Conference on Information Systems (ICIS 2017), Seoul. From https://www.researchgate.net/publication/ 319965259_Hands_on_the_wheel_Navigating_algorithmic_management_and Uber_drivers\%27_autonomy

Rosenblat, A. (2016), 'Algorithmic labor and information asymmetries: A case study of Uber's drivers', International Journal of Communication, 10, 3758-3784.

Suriano, J. (2001), Anarquistas. Cultura y Politica Libertaria en Buenos Aires, 1890-1910, Buenos Aires: Editorial Manantial. 
Tassinari, A. and Maccarrone, V. (2019), 'Riders on the storm: Workplace solidarity among gig economy couriers in Italy and the UK', Work, Employment and Society, 34 (1), 35-54.

Tilly, C. (1978), From Mobilization to Revolution, Reading, MA: Addison-Wesley.

Vandaele, K. (2018), 'Will trade unions survive in the platform economy? Emerging patterns of platform workers collective voice and representation in Europe', European Trade Union Institute, Working Paper 2018.5. From https://www.etui.org/ Publications2/Working-Papers/Will-trade-unions-survive-in-the-platform-economy -Emerging-patterns-of-platform-workers-collective-voice-and-representation-in -Europe 